\title{
Rare exstrophy variant with unilateral renal agenesis
}

\author{
Ruchira Nandan (10 , Devendra Kumar Yadav, Prabudh Goel, Anjan Kumar Dhua
}

Department of Pediatric Surgery, All India Institute of Medical Sciences, New Delhi, India

\section{Correspondence to}

Dr Devendra Kumar Yadav; drdevendra@hotmail.com

Accepted 12 July 2021

\section{DESCRIPTION}

A 3-month-old male child presented with continuous dribbling of urine from the lower abdominal wall. The child had an exposed bladder plate with polypoidal mucosa (figure 1). The penis was normal and had no chordee. The prepuce was intact. The urethral meatus was located at the glans tip. An 8-French infant feeding tube could be easily passed through the urethra. Bilateral inguinal hernia was present, which was reducible. The position of the anus was normal.

Ultrasonography showed a normal right kidney and absent left kidney. The urinary bladder was not visualised. Dimercaptosuccinic acid scan demonstrated non-visualised left kidney and normal right kidney (figure 2).

Only two such cases have been reported previously in the English literature. ${ }^{12}$ Both the previously described cases did not have any associated anomaly. Our case is unique as it has associated renal agenesis. Kulshrestha et al described it as a variant of the superior vesical fissure, which itself is an exstrophy variant. ${ }^{2}$ Exstrophy variants are rare congenital anomalies with an incidence of 1 in $4-5$ lakhs. ${ }^{3}$ The term exstrophy variant is under debate because they are similar to classical exstrophy only in having pubic diastasis and divergence of rectus muscles. Their prognosis in terms of urinary continence is better because of the intact sphincteric mechanism. They are associated with different types of congenital anomalies as opposed to classical exstrophy-epispadias

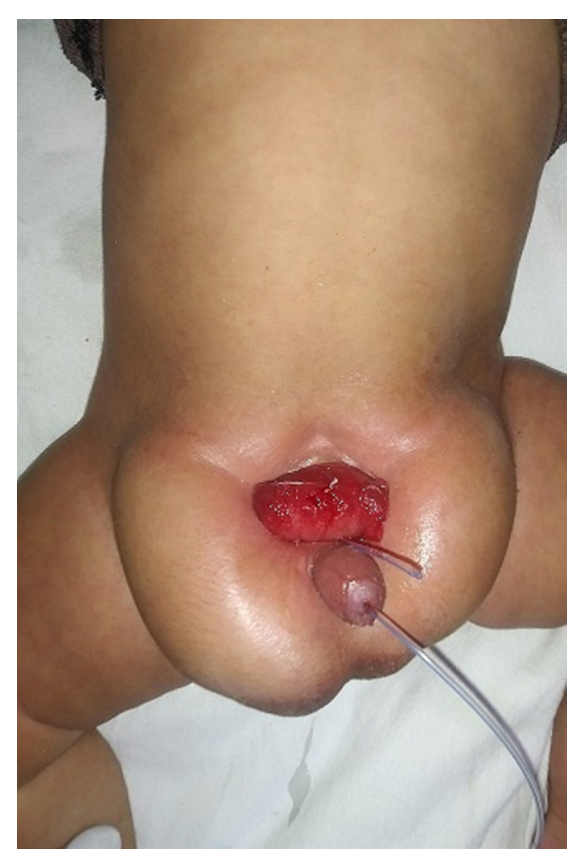

Figure 1 Exposed bladder plate with normal phallus.

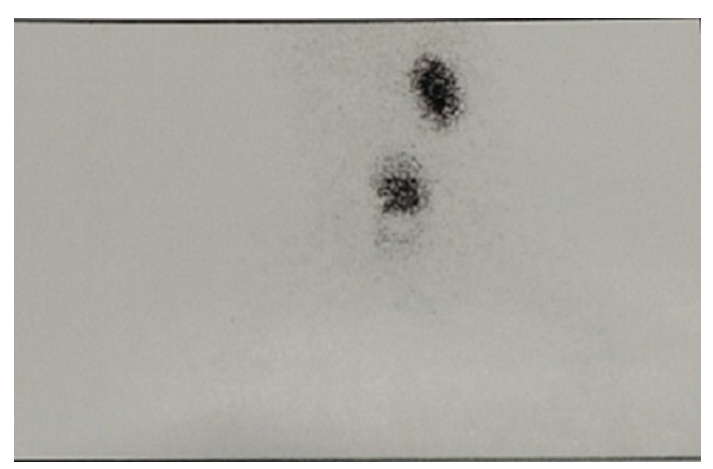

Figure 2 Dimercaptosuccinic acid scan showing left renal agenesis.

complex. ${ }^{4}$ Different types of exstrophy variants have been described, and we also identified a rare exstrophy variant with left renal agenesis.

\section{Twitter Prabudh Goel @ drprabudhgoel}

Contributors Conception and design, acquisition of data or analysis and interpretation of data, drafting the article or revising it critically for important intellectual content, final approval of the version published and agreement to be accountable for the article and to ensure that all questions regarding the accuracy or integrity of the article are investigated and resolved: RN, DKY, PG and AKD.

Funding The authors have not declared a specific grant for this research from any funding agency in the public, commercial or not-for-profit sectors.

Competing interests None declared.

Patient consent for publication Parents/guardians consent obtained.

Provenance and peer review Not commissioned; externally peer reviewed.

\section{Perspective of patient's mother}

I am worried about my child as he is suffering from a rare disease and cannot hold urine. His one kidney is also absent and there is continuous dribbling of urine. The elderly in the family do not want to play with the child because of urine smell. I am afraid that my child will not adjust well in the society if the disease is not cured.

\section{Learning points}

- Exstrophy variants are of different types and have various associated anomalies.

- Exstrophy variants must be investigated for associated anomalies. 


\section{Images in...}

\section{ORCID iD}

Ruchira Nandan http://orcid.org/0000-0002-1563-7771

\section{REFERENCES}

1 Kulshrestha S, Kulshrestha M, Yadav A. Complete bladder exstrophy with a normal phallus: a variant of superior vesical fissure. J Pediatr Surg 2002;37:1354-6.
2 HIGGINS CC. An evaluation of cystectomy: for exstrophy, for papillomatosis, and for carcinoma of the bladder. J Urol 1958;80:279-92.

3 Valioulis I, Levard G, Lottmann H, et al. A rare complex bladder exstrophy variant. BJU Int 2000;86:398-400.

4 Gupta DK, Charles AR, Srinivas M. Exstrophy variants: should they be considered malformation complexes separate from classic exstrophy? Eur J Pediatr Surg 2003;13:377-82.

Copyright 2021 BMJ Publishing Group. All rights reserved. For permission to reuse any of this content visit

https://www.bmj.com/company/products-services/rights-and-licensing/permissions/

BMJ Case Report Fellows may re-use this article for personal use and teaching without any further permission.

Become a Fellow of BMJ Case Reports today and you can:

- Submit as many cases as you like

- Enjoy fast sympathetic peer review and rapid publication of accepted articles

Access all the published articles

Re-use any of the published material for personal use and teaching without further permission

\section{Customer Service}

If you have any further queries about your subscription, please contact our customer services team on +44 (0) 2071111105 or via email at support@bmj.com.

Visit casereports.bmj.com for more articles like this and to become a Fellow 